\title{
APLICAÇÃO DA CARTA GEOTÉCNICA DE CUIABÁ
}

\author{
Anna Regina FEUERHARMMEL \\ José Antônio Lemos dos SANTOS \\ Prudêncio RODRIGUES
}

\begin{abstract}
RESUMO
A cidade de Cuiabá tem enfrentado problemas decorrentes da interação do meio físico e do uso e ocupação do solo. Buscando a melhor compreensão desse processo, para estabelecer medidas corretivas e preventivas, elaborou-se uma Carta Geotécnica, visando fornecer diretrizes ao planejamento urbano, à elaboração do Plano Diretor e à legislação de uso, ocupação e parcelamento do solo urbano. Ao completar três anos de utilização da Carta, tentouse uma breve avaliação.
\end{abstract}

\section{ABSTRACT}

The city of Cuiabá has suffered problems resulting from the interaction between the physical environment and the use and occupation of the soil. Searching for a better understanding of this process in order to establish corrective and preventive measures, a geotechnical map was formulated aiming at providing guidelines to urban planning, development of a master plan and laws for the utilization, occupation and parcelling of urban soil. After three years of use of this map, we try here a brief assessment.

\section{CONSIDERAÇÕES INICIAIS}

A cidade de Cuiabá surgiu no século XVIII em função da extração do ouro, dandose a ocupação condicionada ao meio físico, nas áreas de colinas com o arruamento imediatamente relacionado às curvas de nível. $\mathrm{O}$ crescimento populacional pouco significativo se mantém até a década de 60 deste século; a partir de então, como decorrência da política de expansão de fronteira agrícola, o movimento migratório gera crescimento acelerado e desordenado, iniciando as primeiras ocupações em áreas desfavoráveis quanto ao meio físico.

Com a necessidade de elaborar o Plano Diretor de Desenvolvimento Urbano - PDDU, a Prefeitura Municipal de Cuiabá implantou o Instituto de Pesquisas e Desenvolvimento Urbano - IPDU. O IPDU celebrou um convênio com a Universidade Federal de Mato Grosso - UFMT, no sentido de obter estudos básicos para o Plano Diretor, dentre esses a Carta Geotécnica.

A Carta Geotécnica de Cuiabá foi elaborada por uma equipe interdisciplinar e multi-institucional, formada por professores da UFMT, técnicos de órgãos municipais, estaduais e pela assessoria técnica do Instituto de Pesquisas
Tecnológicas do Estado de São Paulo S/A IPT, obedecendo à orientação principal de oferecer as informações do meio físico de interesse para otimizar a gestão do uso e da ocupação do espaço urbano.

\section{OS PRINCIPAIS PROBLEMAS URBANOS E AMBIENTAIS DE CUIABÁ E A CARTOGRAFIA GEOTÉCNICA}

A cidade de Cuiabá tem enfrentado problemas decorrentes da interação do meio físico e do uso e ocupação do solo, notadamente a ocupação das margens do rio Cuiabá, de sua planície de inundação e de seus afluentes; extração de areia do leito do rio por dragagem descriteriosa; alterações topográficas devido à extração de argila, cascalho, areia de goma e ouro; poluição dos cursos d'água pelo lançamento de efluentes in natura, invasão de áreas degradadas após a garimpagem; depósitos de lixo; ilhas de calor; dentre outros, acarretando sérias dificuldades à população e ao poder público. (RODRIGUES et al., 1992.)

Buscando compreender as relações do meio físico e os problemas decorrentes do uso e da ocupação do solo, foi elaborada, com ampla participação da comunidade local, a 
Carta Geotécnica de Cuiabá, na escala 1:25.000, apresentando sete unidades geotécnicas ou unidades homogêneas quanto: às características de interesse do meio físico, aos problemas existentes ou esperados frente às várias formas de uso e de ocupação do solo e quanto às medidas preventivas e corretivas. Essas unidades correspondem ao Canal Fluvial (calhas e barrancas do rio Cuiabá), Diques Marginais, Planície de Inundação (até a cota $150 \mathrm{~m}$ ), Áreas Alagadiças (várzeas e embaciados), Áreas Aplanadas (declividades inferiores a $5 \%$ ), Colinas e Morrotes. (UFMT, 1990.)

\section{BREVE AVALIAÇÃO}

A elaboração de instrumentos técnicos, como a Carta Geotécnica, se faz cada vez mais necessária ao planejamento urbano, ampliando a compreensão da dinâmica do processo de urbanização. A Carta Geotécnica de Cuiabá tem sido utilizada, notadamente pelo Instituto de Pesquisa e Desenvolvimento Urbano, para o enfrentamento dos problemas urbanos e ambientais.

A abordagem metodológica da Carta Geotécnica de Cuiabá revela uma adequação ao nível de expectativa da comunidade, na medida em que a sua configuração expressa nitidamente compromisso com a solução de problemas vivenciados pela população. Permite imediata aplicação, tendo em vista que teve como mote norteador os problemas com que a cidade se depara.

A avaliação de sua utilização no planejamento urbano e ambiental e de gestão de problemas imediatos permite distinguir três níveis de aplicação:

\subsection{Subsídios à formulação de políticas}

- De Desenvolvimento Urbano, notadamente na elaboração do Plano Diretor de Desenvolvimento Urbano (PMC, 1992);

- De Ocupação Territorial e Meio Ambiente, em especial a Legislação de Uso e Ocupação do Solo;

- De abastecimento de água, tendo em vista que a realidade de Cuiabá aponta para a utilização disseminada de sistema de abastecimento isolado através de poços;

- De esgotamento sanitário quanto à favorabilidade ou não da adoção de sistemas isolados como fossas sépticas;

- De Limpeza Urbana quanto ao sistema de tratamento e localização de aterros sanitários.

\subsection{Subsídios a pareceres técnicos}

- Quanto à localização de atividades extrativas não previstas em legislação, ex.: argila, areia de goma, areia lavada e cascalho;

- Quanto à localização de empreendimentos de parcelamento do solo, observando a favorabilidade ou não de ocupação de determinadas áreas.

\subsection{Subsídios a estudos técnicos}

- De expansão do perímetro urbano;

- De localização de equipamentos, como cemitérios;

- De localização de loteamentos e habitações populares efetuadas pelo Poder Público Municipal;

- De localização de equipamentos comunitários como escolas e outros.

\section{CONSIDERAÇÕES FINAIS}

A cartografia geotécnica representa oportunidade de amadurecimento técnico na compreensão da dinâmica de apropriação do solo urbano. A sua aplicação garantiu diretrizes no Plano Diretor quanto à ocupação e expansão do perímetro urbano, conhecimento prévio das áreas favoráveis ou não à ocupação urbana, apresentando-se como orientação e justificativa da ação pública na definição de instrumentos normativos de ordenamento físico e territorial.

As ações possibilitadas pela utilização da Carta Geotécnica expressam responsabilidade do poder público em relação à gestão do ordenamento territorial, marcando compromisso com o gerenciamento do bem coletivo que é a cidade.

\section{REFERÊNCIAS BIBLIOGRÁFICAS}

PMC - PREFEITURA MUNICIPAL DE CUIABÁ. 1992. Lei Complementar n ${ }^{\circ}$ 003, 24 de dezembro de 1992, Dispõe sobre o Plano Diretor de Desenvolvimento Urbano de Cuiabá e dá Outras Providências. Gazeta Municipal. Seção I - Das Diretrizes Gerais, p. 4.

RODRIGUES, P.; VECCHIATO, A.B.; SHIRASHI, F.K. 1992. O Meio Físico e a
Urbanização de Cuiabá - MT: Enfrentamento dos Problemas. In: PRIMEIRO SEMINÁRIO INTERNACIONAL SOBRE PROBLEMAS AMBIENTAIS DOS GRANDES CENTROS URBANOS - ECOURBS'92. Rio de Janeiro, RJ. Volume de Resumos. Sociedade Brasileira para a Valorização do Meio Ambiente, p. 24. 
Rev. IG. São Paulo, Volume Especial, 1995

UFMT - UNIVERSIDADE FEDERAL DE MATO GROSSO. 1990. Carta Geotécnica de Cuiabá, Convênio
Prefeitura Municipal de Cuiabá. Relatório Final, v. 1.

Endereço dos autores:

Anna Regina Feuerharmmel - Instituto de Pesquisas e Desenvolvimento Urbano, Prefeitura Municipal de Cuiabá. Palácio Alencastro S/N $3^{\circ}$ andar - 78.000 - Cuiabá - MT

José Antônio Lemos dos Santos e Prudêncio Rodrigues - Departamento de Geografia, Universidade Federal de Mato Grosso. Cidade

Universitária - 78070-900 - Cuiabá - MT - Brasil. 